\title{
Quest for Miracle Healing and Prosperity in the New Religious Movements in Nigeria: Its Causal Phenomena
}

\author{
Benjamin Chukwunoso Nwokocha \\ https://dx.doi.org/10.4314/jrhr.v13i1.8
}

\section{Abstract}

This paper $x$-rayed in a very precise form the theology of miracle healing and prosperity message expounded by the preachers of the new generation churches in Nigeria. Since however, this title is a bit too vast and ambitious for the limited scope and time of the discourse, the paper, therefore, investigated the salient issues involved in the theology of miracle healing and prosperity message as expounded by the preachers of the new generation churches in the south-east of Nigeria; though south-east/Igboland and Nigeria are used interchangeably. It also investigated how the theology amongst other factors has occasioned the proliferations of new religious movements in Nigeria. Other issues that are connected to the growth of the new religious movements in Nigeria and Igboland in particular examined in this study included the African's quest for power, cultural identity, ethnic identity, health, and economic emancipation. The purpose of this study is to $x$-ray the impact of prosperity preaching and quest for miracle in the new religious movements in Nigeria. The findings showed that the import of the new religious movements in Nigeria is occasioned by the excesses of the colonial and missionary overlords in the pre-colonial Nigeria. Findings also indicated that the new religious movements came to fore in Nigeria as a religion of the oppressed in the cultural, social, religious and political spheres. It was developed as a rescue mission to the already degraded religion and tradition of the people. The methods of approach include historical and phenomenological methods. The study however recommends the theology of prosperity and miracle healing as a 
Nwokocha: Quest for Miracle Healing and Prosperity in the New Religious Movements in Nigeria: Its Causal Phenomena

correct and sound teaching for not just the new religious movements but for all Christian churches in Nigeria. The study equally advocates that it would not be expounded beyond proportion so that the church would not be reduced to a mere miracle centers.

Keywords: New Religious Movements, Miracle, Healing, Prosperity

\section{Introduction}

The focus of this study is to trace the causal factors to the emergence of the new religious movements in Nigeria. It will adopt an analytical approach in investigating the new religious movements and its activities in Nigeria. The study will apprise the salient issues that are involved in the "newness" in the African Initiated Churches (AICs). One of which being a quest for healing and prosperity in the New Religious Movements in Nigeria; other factors which included the indigenous people's quest for spiritual, cultural, ethnic, health and for economic emancipation system for their own personal and practical purposes of healing or security. (Nmah, 2017).Specifically, the interest of this research work is to examine the impact of these factors to the new religious movements in Nigeria. The findings showed that the quest for miracles, healing and prosperity is the major propelling factor for the continued proliferations of the new religious movements in Nigeria. Further findings revealed that the new religious movements are a religion for the oppressed in cultural, social, religious and political spheres. According to Bowen (1996):

Missions were often guilty of a failure to love. They did not listen to the Africans. Therefore they often failed to relate the Good News to African issues such as witch-craft, spirits, ancestors, land and community. They also failed to bring the holistic deliverance from evil which Africans longed for. The missionaries did not realize that the Bible they had brought would judge their culture just as it judged African culture... They 
competed with one another, and thus threatened African tribal life with conflict and insatiability. (p. 47).

The above summation may not be limited to Nigeria as a society of people and cultures, it may equally be useful to other-geographical areas of the world where substantially similar phenomena. That is basically why this study will examine the causative factors for the "protest" or "proto-nationalist" movements among the oppressed people of Nigeria. Above all, the quest for spiritual powers, miracles and signs and wonders have accounted for the religious movements in search for healing and security.

Consequently, these new religious movements which are also regarded as the religions of the oppressed show a state of religious independency and the rise of nationalism, the abuse of politics, the derogatory assault of the basic African values and customs amongst others were the major reasons that led to the emergence of the new religious movements in Nigeria (Nmah, 2017). Basically, the research work deals with the role of miracle, healing and prosperity message in the religious movements and its plurality of disciplines and classification systems.

For conceptual clarifications, the "new religious movements here refers to a substantial departure from the classical orthodox Christian religious traditions. In the customary parlance, the term may represent a territory that is not under the control of external religious powers. In ecclesiastical usage as adopted in this study stands for the principles that individual congregation or church is an autonomous and equalitarian society free from any external ecclesiastical control (Barrett,1970). The term "new" or "newness" as applied in this study is used to describe these movements because, in historical terms of religious form and content, they are newer than the older form of Christianity from which they separated from. It is also because of their relative new doctrines and ideologies that they are considered new (Barrett, 1970, and Nmah, 2008). The problem that this study 
intends to solve is that the pheumatological emphasis and the demand for manifestations of the power of the spirit through miracle, healing and prosperity as expounded by the new religious movement in Nigeria is not a false theology. This is because miracle, signs and wonders is supported in the scripture. It is because the new religious movement of Nigeria have embraced and expounded it is the reason for their rapid growth and development to the detriment of the orthodox/mission churches whose existence are threatened because of their vehement stance on the religious practice. The only clause the study attached to the prosperity gospel message is that there should be a controlled quest for miraculous healings and prosperity preaching in the church. Again, diabolical means should not be employed to induce miracles otherwise it will turn to magic. Above all, Christians should shone desperation and learn to exercise an absolute faith in God for God's time is the best. Aside from these conditions, miracle, healing and prosperity is an acceptable Christian experience.

Moreover, the research objectives of this study include the following:

- Investigate some of the factors that favoured the growth and development of new religious movements in Nigeria

- X-ray the activities of the religious movement in Nigeria

- To create awareness to the mainstream(missionary) churches on some of the issues involved in the new movement

- To explore the implications of the new religious movement to Nigerians especially the mission churches

- To investigate the factors (features) that made the new religious movement attractive to many Nigerians especially the Igbo Christians.

- Expound the theology of the prosperity gospel 
The basic significance of this study is that it offers valid and insightful resource materials to the religious, sociological, and anthropological researchers especially the church historiographers. This is because they can always consult this research work to gain useful information on the salient issues that borders on the new religious movement in Nigeria. Most especially, the study will be of very significant to the mainstream(missionary) churches in Nigeria in because it addresses the issues of the new religious movement that have threatened the existence of the mainstream churches. The methods of approach used in this study include historical and phenomenological approaches with primary and secondary methods of data collection. Historical research studies are the making use of the past events in an attempt to interpret the cause of events, and their effects in the present events. The purpose of an historical method is to obtain a better understanding of the present, through a careful evaluation of the past and an intelligent reconstruction of the future. The phenomenological approach on the other hand is a qualitative research method that is used to describe how human beings experience a certain phenomenon. Smith (2003) defined phenomenology as a study of structure of consciousness as experienced by the first-person point of view. Phenomenology could also be defined as an approach that concentrates on the study of consciousness and objects of direct experience. The primary source of data collection employed in this study involved oral interviews while secondary source entails books, journals, and internet materials. These furnished the researcher with the basic information needed for the work.

\section{The Nature of Newness of the Religious Movements in Nigeria}

For the purpose of classifications, there are two main kinds of Christian new religious movements in contemporary Africa and Nigeria in particular. First are those who have, for various reasons, 
tergiversated from the historic missionary-founded churches. They are sometimes referred to as schismatic or separatist movements. These categories of churches are known for their continued reflection on the ideologies of their mother churches, despite intensive internal changes, adaptations, inculturation, incarnation, and method of worship. The second group of the movements is commonly referred to as "spiritual" or "spiritualist" (sometimes "spiritis") movements or churches because of their emphasis on pneumatology and practice of glossolalia and spiritual healing (Mbon, 1999).

With the emergence of these movements sometimes as a rival to the parent or mother churches, such movements are considered as an outlaw and a separatist group and such are disowned by their mother churches. In Nigeria, the vast majority of the said new religious movements have lost harmonious interaction and cordial relationship with the mission churches. Nigerian Pentecostalism, for example, does not usually share in certain features with the European founded churches. This is as a result of the sharp contrast that existed between the newness of the new religious movements and the orthodoxy of the Mission founded churches in Nigeria. The emphasis of the new religious movements is stressed on the importance of prayer, the presence and power of the Holy Spirit made evident in charismatic gifts and visible signs and results. These are believed to represent the spiritual gifts manifested due to the second baptism of the Holy Spirit through fasting, faith healing, prophecy(dreams, visions, predictions), and ecstatic motor phenomena like trances, speaking in tongues and various forms of possession by the spirit(Turner,1979).

This pheumatological emphasis and the demand for visible manifestations of the power of the spirit are the major characteristics of the new religious movements in Nigeria (Ndiokwere, 1995). For example, the first movement with these emphasis arose among the Ijaw people in the Niger Delta area of Nigeria late in 1915 through the activities of Garrick Braid, who was already known for his 
spiritual power in prayer and healing as a member of the Anglican and all-African Niger Delta pastorate church. Braid's method of healing seems to have been through faith consequent upon his prayers and imposition of hands, and such was his reputation as a man of spiritual power that many sought healing through drinking or anointing themselves with the water in which he had washed. There are also a role of music, dance, prophecy and divination during his divine worship (Ndiokwere, 1995).

The most common feature amongst the new religious movements in Nigeria is a display of ecstatic phenomena vizaviz speaking in tongues, prophecy, dreams, removal of shoes, dancing and emotional display of joy(Nmah,2017). The ecstatic state is believed to be a way of receiving supernatural endowments. From a psychological point of view, Ndiokwere (1995) described ecstasy as:

A withdrawal of consciousness from circumference to centre; a state in which the absorption of the mind in one idea, in one desire, is so profound that everything else is blotted-out, a state in which consciousness of self disappears. Such a condition, it is said, could as well be induced by the use of narcotics, alcohol, music and dancing. It could also come by contemplating and complete spiritual concentration as well as by prayer. (p. 52).

The religious group with profound belief in ecstaticism are collectively referred to as "Aladura"(praying) churches. Moses Orimolade Tunolase and Christiana Abiodun Akinsowo in 1925 belong to this category.

\section{Causal Factors for the Emergence of the New Religious movements in Nigeria}

There are lots of causal factors that led to the emergence of the new religious movements in Nigeria. Some of them include; quest for personal identity, religious identity, ethnic identity, cultural and academic identity amongst others. Other factors include economic 
factor, ecclesiastical mal-administration, quest for miracle, healing and prosperity (Ndiokwere, 1995 and Barrett, 1970).

\section{Miraculous Healing}

It has been observed that quest for miracle and healing have necessitated the wanton proliferations of the new religious movements in Nigeria. The leaders of the religious movements are believed to be in possession of charismatic gifts and power to command healing and miracle in the lives of their congregations. According to Turner (1979), he succinctly submitted thus:

These spiritual gifts are often regarded as due to the "second baptism of the spirit" which include faith healing, prophecy (dreams, visions, predictions), and ecstatic motor phenomena like trances, speaking in tongues and various forms of possession by the spirit.(p.122).

In rural and urban areas, they created prayer houses to meet the demands of their clients for prosperity, health and success in their endeavours. They speak to the people in the accent they will understand (Nmah,2017). In some churches and prayer ministries, consultation fees are paid before one is allowed to see the Pastor, Evangelist, or the visioner. The amount paid varies depending on the choice of the individual. Sometimes, the motive of some fake pastors is to extort money or defraud the unsuspecting people. There was a story reported by Sun Newspapers dated August 16, 2020, titled "Delivered to Death". Here, a woman was led to see a Pastor to deliver her only daughter after a prophetess prophesied she was possessed of evil spirit. The said pastor told her that the girl would undergo a three day prayer session and demanded the sum of five thousand naira. After the three days, the woman went for her daughter only to meet a gory sight of miracles; a situation where her daughter was almost half dead following the magic-like miracle that was being carried on her. Apparently, this is the least of the problems associated 
with the wanton quest for miracle and healing amongst the new religious movements in Nigeria and that does not again mean that there are no genuine ones among them and should not again be the reason to discredit the potency of miraculous healing in the church.

\section{Religious, Academic and Ethnic Identity}

More often than not, some of the new religious movements are associated with tribe, religious and academic factors. On the ethnic and academic identity, the movements sometimes used the facilities of the older churches for ministerial training and at times its leaders are only self-trained. For example, the Christ Apostolic church, the largest independent church in Nigeria in the early 90s, has its own education system with six grammar schools, and a teacher-training college. It has produced many reputable graduates today. Similarly, the highly individualistic Holy Apostles' Community in its remote lagoon-bound city of Aiyetoro in Nigeria has its own school system and is seemingly doing well.

Consequently, the new religious movement has contributed immensely in promoting the indigenous cultures and traditions. According to Turner (1978), the new religious movements interpret the scripture to suit their cultural milieu. They adopt a style of worship which is more African in orientation, they further developments within the traditional religious system and at the same time attempt to revitalize or remodel the traditional Christian forms of religious worship. Movements of this type (typology) include the Reformed Ogboni Fraternity(1914), the National Church of Nigeria(1948) and other related churches that are usually antiEuropean.

Moreover, African search for black identity and power is the aim of the independent church movement. The major task of the new religious movement in Nigeria however, is to interpret the message of the church to the accent and culture of the people. The summation of 
its theology is based on Psalm 68:31, which says, "Ethiopia will quickly stretch out her hands to God". It builds on the concept of Africa for the Africans. Kalo (1998) averred that the theology of the new religious movement stands for the following; radical recapture of the lost land, radical withdrawal of whitianity from all African institutions, joint action of local African anti-colonial movements of liberation, pursuit of a true biblical religion which will save man from material and spiritual bondages. They comprise of defensive theological system from which places politico-economic and sociological liberation from economic colonialism, imperialism, and neo-colonialism.

\section{Emphasis on Prosperity Theology}

Prosperity theology is a form of Christian teaching that emphasizes God's will for the prosperity of all believers, to be attained through faith, devotion, tithing, and positive confessions. Quantifying the prosperity preaching is not a simple exercise. In Nigeria, it was spearheaded by the likes of Benson Idahosa in the 1970s. Today, its main proponent is bishop Oyedepo, one of the most popular pastors in Nigeria. He has been known to be vocal on the church's position on tithing and was reported in one of his message when he openly said "if you are not a tither, you will end up a beggar". In his church as in other new generation churches, tithing is a core doctrine and reasonable number of the congregation pays $10 \%$ of their monthly income as tithe.

Precisely, prosperity gospel in the context of Pentecostalism is a strong belief and teaching that emphasizes God's will for the prosperity of all believers, to be attained through faith, devotion, tithing, and positive confessions. And although the two remain distinct in many cases, from the dusty parishes of rural places in Nigeria to the urban villages of Lagos, the wealth and get rich-quick syndrome embedded in the prosperity gospel has become 
synonymous with Pentecostalism. Quantifying the wealth and malpractices associated with prosperity preaching is a heuclean task, however, its roots, though, not explicitly Christian tradition but can be traced to a nineteenth century American tradition spearheaded by Waldo Emerson and William James. Gradually, the tradition gained ground in Nigeria through Arshbishop Benson Idahosa before it gained a wider publicity amongst the Nigerian Pentecostal preachers today. It later influenced other Christian movements including the mainstream and new religious movements in Nigeria.

In 2011, Forbes (2015) released a list of the five richest pastors in Nigeria, all of whom were Pentecostal preachers. They had a combined net worth of around\$235 million (Over \#30 billion at the time). Bearing in mind the high levels of poverty in Nigeria, the considerable wealth of prosperity preachers-many of whose members are far less well off-has been a longstanding topic of controversy. Indicating the close nexus between prosperity gospel and poverty, studies have shown that poor individuals are more drawn to the prosperity gospel. Against this backdrop, it is easy to understand why the prosperity gospel has spread by offering people in hardship a means of controlling their seemingly uncontrollable situations. It promises health for a believer who abides by its tenets. For those living in poverty, this message of hope can be very powerful and indeed comforting.

\section{Implications of Prosperity Gospel to the Growth and Development of New Religious Movements in Nigeria}

By aligning the growth and development of the new religious movement in Nigeria, prosperity gospel could be said to have, in many ways, fostered the proliferations of the religious movement in Nigeria. It may be coincidence, but the wave of prosperity gospel in Nigeria gained momentum just when Nigeria began to adopt neoliberal policies in 1980s. However, it is worth considering the 
extent to which religious messages like the prosperity gospel, have in some way (perhaps even unconsciously) limited the extent to which citizens are compelled to hold the government more accountable. It is also worth recognizing that many Nigerians find fulfillment in the prosperity gospel. Still centred on a relationship with God, it provides spiritual satisfaction along with the positive message of hopefulness in difficult situations.

There is also an inspirational quality surrounding prosperity gospel that makes it so attractive. These churches are attended by people from across various social classes and for the less privileged, watching the wealthier believers testify and attribute their successes to their adherence to the prosperity gospel, makes it worth adopting. And for those employed by megachurches-pastors, drivers, teachers, technicians, musicians, amongst others, this theology has become an important source of livelihood. It is however unlikely that the popularity of prosperity gospel will wane anytime soon. It therefore more preferable that the mainstream churches instead of opposing this teaching will rather embrace it, though in a more reformed way.

\section{A Way Forward to the Theological Misunderstanding that Exists between the Mission Churches and the New Religious Movements on the Issue of Miracle and Prosperity Gospel}

On a way forward to the inherent chasm and religious dichotomy that have long existed between the mission churches and the new religious movements on the issue of prosperity gospel, this study advocates that the leadership of all Christian denominations in Nigeria should have a common front as regards to the teaching. The mission churches in particular should instead of out rightly condemning the belief system should rather see a way to fine tune it to better address the plight of the people. This is because of the fact that people do not easily change their ideas when it concerns money and wealth. So, hatred and rancour cannot solve the problem but a good understanding of one 
another.This is occasioned by the fact that the message have permeated into the sub-conscious minds of Nigerian Christians. People are testifying to the efficacy of the gospel in their day to day religious endeavours.

However, one of the causalities of prosperity gospel is due to the economic decadence of Nigeria. That is why the gospel is otherwise referred to as the health and wealth gospel, or "name it, claim it gospel" which has become one of the fastest growing emphasis within the new religious movement. Prominent in Pentecostal and charismatic churches, it has accounted for the rapid spread of the new religious movement in Nigeria because the gospel focuses primarily on material well-being and success in this life which mostly includes abundant financial resources, good health, clothes, housing, cars, promotion at work, success in business as well as other endeavours in life. The gospel asserts that believers have the right to the blessings of health and wealth and that they can obtain these blessings through positive confessions of faith and the "sowing of seeds" through the faithful payments of tithes and offerings. The extent of material acquisition and well being is often equated with God's approval. These are the already made framework with which the new religious movement in Nigeria has gained a wider publicity in the name of prosperity gospel.

Hitherto, the problems are whether these new religious movement will defend and consolidate such a gospel with the truth of the scriptures. This is why this study is of the view that instead of attacking the gospel, the Mainstream church should form an alliance with the new religious movement to develop a more balanced teaching and theology as regards to the gospel of prosperity. Again, this study advocates that the mainline churches should demonstrate tolerance towards the new religious movements. They should also be flexible enough to accommodate positive changes from time to time including the gospel and theology of prosperity, since the church is 
dynamic. According to Nwabufo (2018), a materially prosperous society, which is free from all inequalities is a religious coherent and egalitarian society. This is why the gospel needs not to be entirely discarded but reformed for an overall well being of the people.

\section{Conclusion}

In conclusion, this study classified the concept of "newness" as comprising of a new movement distinct from the orthodox belief and practice. It is undoubted true that new discoveries cause people to change the way in which they understand human life and religious experience. The newness in the new religious movements engendered evangelistic awakening and spiritual revival among the Pentecostal group members. Some of the features in the new religious movements previously condemned by the mission churches could now be seen in the main line churches. Sadly, the new religious churches are greatly promoted by the populist prosperity preaching which have been attracting the crowds as they search for wealth, healing, and deliverance without any serious transformation in their lives. It is also pertinent to say that that causal factors that ensured the emergence of the new religious movements in Nigeria is based on the Europeans neglect and disparaging of the indigenous people and their cultures. Ekechi (1972) observes missionaries utterances that Africans have no brain to think for themselves. This is among the wrong primordial and confrontational sentiments against African society for their refusal to swallow hook, line and sinker the missionaries' unbecoming attitude of making them perpetual servitude. It is therefore in response to this derogatory attitude to the African people and their culture that led to the emergence of the new religious movement that is fast growing in leaps and bounds today. 


\section{References}

Ayandele, E.A.(1966). The missionary impact on modern Nigeria 1842-1914. London:Longman.

Barrett, E.(Ed.) (1970). Schism and renewal in Africa. Nairobi: Oxford University Press.

Bowen, R.(1996). So I send you: A study guide to mission. London: SPCK.

Idowu, B. (1965). Towards an indigenous church. Ibadan: Oxford University press.

Ndiokwere, N.I.(1995).Prophecy and revolution. London:SPCK.

Nmah, P.E.(2008). Religion and society in Africa. Enugu: Rabboni.

Nmah, P.E.(2017). What is new religious movements in Africa?An analytical approach.

Igwebuike: An African Journal of Arts and Humanities. Vol. 3. No.2.

Turner, H.W.(1967). The history of an African independent church: the church of the Lord (Aladura). Volume 1. Oxford: University Press.

Turner, H.W.(1978). The approach to Africa's religious movement in religious innovation in African society. Holland: Afrita.

Turner, W.H.(Ed.). (1979). Religious innovation in Africa: Collected essays on new religious Movements. Bosten: G.K. and Co.

Benjamin Chukwunonso Nwokocha is a lecturer in Department of Religion and Human Relations, Nnamdi Azikiwe University, Awka. 